\title{
Application Of Six Thinking Hats Method In Improving Students' Thematics Learning Outcome In Elementary School
}

\author{
Sidrah Afriani ${ }^{1}$, Nur Atiqa ${ }^{2}$ \\ \{sidrah.afriani@unm.ac.id ${ }^{1}$ \} \\ ${ }^{1,2}$ Primary Teacher Education, Faculty of Education, Universitas Negeri Makassar, \\ Makassar, Indonesia
}

\begin{abstract}
The purpose of this study was to improve the thematic learning outcome using the Six Thinking Hats method for fifth grade students at SD Negeri 10 Manurunge, Tanete Riattang District, Bone Regency. This research is a classroom action research using descriptive qualitative method. The focus of research is the application of the Six Thinking Hats method and student thematic learning outcomes. The research subjects were teacher and fifth grade students of SD Negeri 10 Manurunge, Tanete Riattang District, Bone Regency. This research was conducted in two cycles where each cycle consisted of planning, implementing, observing, and reflecting. Data collection techniques were observation, tests, and documentation. Data analysis techniques were data collection, data reduction, data presentation, and conclusions. The results showed that there was a significant increase in the application of the Six Thinking Hats method to students' thematic learning outcome. It can be concluded that the application of the Six Thinking Hats method in the thematic learning of fifth grade students can improve students' learning outcomes.
\end{abstract}

Keywords: Six Thinking Hats method and Thematic Learning Outcome

\section{INTRODUCTION}

Indonesia has undertaken lately many steps to improve the quality of teaching in schools due to the global demand and competition. One of the objectives leading the recent changes is to ensure that upon their graduation, students possess higher order thinking skills as well as become excellent generations who are ready to compete and have character starting from elementary education. Based on the regulation of the Minister of Education and Culture of the Republic of Indonesia Number 12 Year 2018, improving the quality of primary and secondary education is important in term of interactive learning that is able to involve students to encourage creativity and critical thinking skills. To achieve the goals, teachers are encouraged to create dynamic classroom environment in order to infused thinking skills for students to gain deeper understanding from the meaningful and transferable knowledge [1]. 
The intended learning process not only involves students' low-level thinking processes such as remembering and understanding, but also make students to be able to think critically, analyze the effects or consequences of something, compare and create something new that is known as high-level thinking. In fact, students in this modern era faces more complex problems and need to think in the higher level not merely to know and to understand. Susmuth (2007) in Marcelo [2] argues that the modern world requires students to deal with a greater range of issues than the learners of the past did. These issues are also more complex thus it is expected that teachers are equipped with concepts and strategies to address these pressures of modern education.

Thematic learning in elementary schools begins with a specific theme and is associated with concepts and good practices in children's community and vicinity so the learning becomes more meaningful. A meaningful learning process which is supported by the existence of teaching methods that support students' thinking skills such as critical and innovative thinking can improve learning outcomes. Learning outcomes are influenced by internal and external educational factors [3] which include self perception, motivation, parental involvement, safety, school climate, teacher's method. There has been a rising awareness in Indonesia in the value of innovation and critical thinking among teachers [1], [4], [5]. However, it is not certain that Indonesian teachers, particularly those in primary schools, acquire relevant knowledge and skills to apply critical thinking to their practice.

Edward de Bono Six Thinking Hats method aims for enhancing thinking and simplifying it at the same time [6]. It is believed that using this method, teachers can facilitate students to use critical thinking in classroom activities. Kivunja [7] says "critical thinking is the cognitive process that creates the ability to interpret, analyze and evaluate information, arguments or experiences with a set of reflective attitudes, skills and abilities to guide our thoughts, beliefs and actions" (p. 431). Thus with the application of the Six Thinking Hats Method in the classroom, teachers are expected to be able to involve the stages of students' thinking processes, so learning will not make students passive and allow the learning process to be active, critical and innovative. Six Thinking Hats method has some rules and each color of hats develops certain thinking abilities in students so students can think with multiple points of view [7]; white color focuses on information such as facts, data and graphics; black color requires critical thinking such as assessing and analyzing; green color contains questions involve answers showing students' ability to think creatively; yellow hat invites students to think positively and logically; red hat leads students to give their feelings about a concept; finally, blue hat focuses on decision making or thinking thoughfully [8].

This method involves one type of student thinking activity at one particular time using 6 colored hats followed by several questions that can encourage students' thinking skills and their learning outcomes. Some studies [1], [9]-[11] have proven the effect of Six Thinking Hats on Students' Learning success. Due to the enlightening result of these studies, the researcher conducted a classroom action research with the application of this method in the thematic learning in elementary education level. From the preliminary observation conducted at the school, not all students in the fifth grade were active in the group activity, some groups only have one or two members who did the whole activities. The learning activities did not reflect the involvement of students' higher thinking skills and mostly focused on teachers modelling and textbook-oriented. These result in the low learning outcomes of the students. Based on the assessment documents, from 33 students, only 14 students or $42.42 \%$ achieved the Minimum Mastery Criteria and 19 students or $(57.57 \%)$ were under Minimum Mastery Criteria (75 standard). 


\section{Research Method}

This research uses descriptive qualitative method and was conducted at Elementary School 10 Manurunge, Tanete Riattang District, Bone Regency. The participants of this research were 33 fifth graders consisting of 20 male and 13 female students. There are four stages in this research, namely planning, implementing, observing, and reflecting. Data collection techniques used were observation, tests and documentation. The data were then analyzed using qualitative analysis techniques, namely data collection, data reduction, data presentation and conclusion drawing. Indicators of success in this study are seen from the aspects of the process and aspects of student learning outcomes in thematic learning (Theme 8 Environment is our friend)

In the planning stage, the researcher invited the teacher who gave information on the students' characteristics and learning to develop lesson plan, learning media, test and students worksheet in accordance with Six Thinking Hats Method. Students and teachers observation sheets were also developed to see step by step of the learning process whether had been accordance with the planned lesson plan. The aspects of learning process and students learning outcomes are the indicator of success in this study in which the learning process is considered successful if in good qualification and students learning outcome reach the minimum mastery criteria of 75 .

In the implementation stage, the learning process is based on the lesson plan and the use of six colors hats by students in group after the presentation of material by the teacher. The hats contain a question based on each function. Each student in the group put on the hats and worked based on the questions they got in every hat, after that they took other hats so that they completed different level of thinking. After wearing all the hats, students then discussed their answers in the group and share their discussion to the whole class. In the observation stage, observer who was the teacher of the class observed from the beginning to the end of the learning activities, monitored the students' activities, attitudes, and behavior when learning took place based on the observation sheet. In the reflection stage, researcher reflected the learning process based on the observation result, documentation and input from observer to search for improvement in the next cycle.

\section{Result and Discussion}

The application of six thinking hats method in the first cycle was in the moderate category since the students had not been familiar with the method, researcher should explain the method repeatedly to the students. The classroom was a bit noisy since some of the groups did not follow the rules explained by the teacher before starting the activity. There were students who did not get the chance to work on some other hats due to the duration of time, and the length of exceeding time spent by the members who got the hats. When reporting their group discussion in front of the class, some students looked reluctant and nervous. For the students learning outcome, the average score was 74,39 categorized to be moderate with $57,57 \%$. The researcher reflected the learning process in the first cycle and made some improvements. The rules of six thinking hats about the exchange of the hats were attached in every group table also containing the duration of time students should spend on each hat. Sticky notes and flip charts are used to ease students to present their ideas when discussing in the groups and clearly representing the thinking activities in every color hat.

In the second cycle, learning process has been improved to the good category. The researcher did not spend time explaining the activity and students have been familiar with the 
method and work on every hat. The learning outcome showed that 25 students or $75 \%$ reached minimum mastery criteria with average score was 78.42. At the implementation stage, all the learning activities have been carried out (initial activity, main activity, and final activity) even though there were still items categorized to be moderate such as time management during the learning process. The learning process was in accordance with lesson plan made by researcher and teacher. In addition, students' learning outcomes in the second cycle has fulfilled the expected category. This shows the success indicator of the learning process and learning outcome have been achieved. The analysis and reflection of the second cycle showed an increase of learning process and learning mastery criteria.

The discussion result from every group has represented the level of thinking based on the theme 8 -environment is my friend. Students performed the thinking not merely knowing and understanding certain concept, but also to do analysis on certain situation. This is in line with the result of [9] that showed how students' analysis of subjects creatively and their ability to look from different perspectives and also their active participation in the problem-solving process could contribute to their learning success. Students can think of the benefits and the weakness of certain behavior to the environment. They can give opinion on the impact of things and how to solve the problem which might occur. De Bono's Six Thinking Hats equips teachers to develop students' critical thinking and problem solving skills [7]. Every educator should be able to facilitate their students to use their thinking skills as these skills must be developed and nourished to enhance the students' motivation and performance or achievement which will result in long life learner and better motivated students[11].

\section{Conclusion}

The application of the Six Thinking Hats method can improve thematic learning outcomes of fifth grade students in SD 10 Manurunge, Tanete Riattang District, Bone Regency. This is proven by the improvement of the process and students' learning outcomes. Improved learning processes and outcomes of the first cycle in moderate category to a good category in the second cycle with a percentage of $75.75 \%$ achieved the predetermined criteria.

\section{REFERENCE}

[1] KONG Siew Lang, 'Effects of a Cognitive-Infusion Intervention on Critical Thinking Skills and Dispositions of Pre-service Teachers'.

[2] Marcelo Suarez-Orozco, Learning in the Global Era: International Perspectives on Globalization and Education. University of California Press, 2007.

[3] J. Jones, 'The external and internal educational factors that contribute to student achievement and self-perceptions of urban middle school Title I students', p. 209.

[4] - Loving, G.L \&Wilson, J.S., 'Infusing critical thinking into the nursing curriculum through faculty development', Nurse Educ., vol. 25(2), pp. 70-75.

[5] S. Wangensteen, I. S. Johansson, M. E. Björkström, and G. Nordström, 'Critical thinking dispositions among newly graduated nurses: Critical thinking dispositions among newly graduated nurses', J. Adv. Nurs., vol. 66, no. 10, pp. 2170-2181, Oct. 2010 .

[6] I. Ghazi Mustafeh, 'The Effect of Implementing Six Hats Teaching Method on the Performance of the 8th Grade Students in Islamic Education', Int. J. Cross-Discip. Subj. Educ., vol. 6, no. 3, pp. 2242-2249, Dec. 2015. 
[7] C. Kivunja, 'Using De Bono's Six Thinking Hats Model to Teach Critical Thinking and Problem Solving Skills Essential for Success in the 21st Century Economy', Creat. Educ., vol. 06, no. 03, pp. 380-391, 2015.

[8] De Bono, E., (2005). Serious creativity (Translated to Arabic by Alnory). Alriyadh. .

[9] M. F. Kaya, 'The Effect of Six Thinking Hats on Student Success in Teaching Subjects Related to Sustainable Development in Geography Classes', Educ. Sci., p. 6.

[10] M. Khataybeh and N. Salem, 'The Effect of Using the Six Thinking Hats Method on the Development of EFL Female Eleventh Grade Students' Writing Skill in Southern Al-Mazar Directorate of Education', vol. International Journal of Arts and Humanities Vol. 1 No. 4; December 2015, Dec. 2015.

[11] I. Ghazi Mustafeh, 'The Effect of Implementing Six Hats Teaching Method on the Performance of the 8th Grade Students in Islamic Education', Int. J. Cross-Discip. Subj. Educ., vol. 6, no. 3, pp. 2242-2249, Dec. 2015. 